\title{
Studi Kasus Penanganan Pembiayaan Bermasalah di Baitul Maal wa Tamwil (BMT) Hubbul Wathon pada Masa Pandemi Covid-19
}

\author{
Winda Hidayanti ${ }^{*}$, Hesty Juan Kirana $^{2)}$, Anisya May Yustitia ${ }^{3)}$, Harnum Widyaningrum ${ }^{4)}$, Tulasmi ${ }^{5)}$, \\ Titania Mukti ${ }^{6}$ \\ 1,2,3,4,5,6 Fakultas Ilmu Agama Islam, Universitas Islam Indonesia \\ *Email korespondensi: $18423063 @$ students.uii.ac.id
}

\begin{abstract}
The research is a Case Study of Troubled Financing Handling at BMT Hubbul Wathon in the Covid-19 Pandemic. The research method uses a descriptive qualitative approach. In collecting data, researchers used interview techniques with BMT about policies to deal with the economic crisis during the Covid-19 Pandemic. BMT Hubbul Wathon Sumowono is one of the non-bank syari'ah financial institutions that issues a lot of financing products, such as Mudharabah, Musyarakah, Murabahah, and Ijarah financing. In providing financing to customers, an agreement is made in the BMT institution, in which there are several provisions that must be agreed upon by both parties. During the Covid-19 Pandemic, BMT Hubbul Wathon experienced a decrease in both savings, financing and installments. In the Covid-19 Pandemic as well, problematic financing at BMT Hubbul Wathon Sumowono increased by 5\% when compared to the financing provided before the Covid-19 Pandemic. Therefore, this nonbank syari'ah financial institution issued several measures or policies including maintaining liquidity, restrictions in providing financing, and also by adding new customer members.
\end{abstract}

Keywords : Baitul Maal wa Tamwil, Financial Problems, Dispute Resolution

Saran sitasi: Hidayanti, W., Kirana, H. J., Yustitia, A. M., Widyaningrum, H., Tulasmi., \& Mukti, T. (2021). Studi Kasus Penanganan Pembiayaan Bermasalah di Baitul Maal wa Tamwil (BMT) Hubbul Wathon pada Masa Pandemi Covid-19. Jurnal Ilmiah Ekonomi Islam, 7(01), 333-340. doi: http://dx.doi.org/10.29040/jiei.v7i1.1771

DOI: http://dx.doi.org/10.29040/jiei.v7i1.1771

\section{PENDAHULUAN}

Pandemi Covid-19 sampai saat ini masih belum berakhir. Kota Wuhan, menjadi tempat virus Covid19 pertama kali ditemukan, sejak Desember 2019. Wabah tersebut disebabkan oleh virus yang bernama Coronavirus dan telah menginfeksi lebih dari 68.000 jiwa. Tidak hanya di Tiongkok saja, virus ini juga menyebar luas dengan cepat di beberapa negara termasuk Indonesia. Di Indonesia memiliki kasus yang terinfeksi berjumlah 344.749 jiwa dan meninggal berjumlah 12.156 jiwa, pada pertengahan Oktober 2020. Berdasarkan data yang ada, Indonesia memiliki angka kematian tertinggi di urutan ke 17 dari berbagai negara. Tersebarnya Wabah Covid-19 ini selain membawa dampak pada kesehatan namun juga berdampak pada perekonomian global. Manteri Keuangan Republik Indonesia, Sri Mulyani Indrawati, mempredikasi bahwa pertumbuhan ekonomi tahun 2020 mencapai minus $1,7 \%$ sampai dengan $0,6 \%$ (KEMENKEU, 2020).
Dampak positif dirasakan oleh masyarakat karena mengurangi angka kemiskinan dan pengangguran. Ditemukan sekitar 3 juta nasabah BMT mendapatkan biaya dari BMT seluruh Indonesia (Zulkifli, Zulfadli, \& Hamzah, 2016). Tingginya permintaan masyarakat guna mendapat pembiayaan dari BMT dikarenakan masyarakat sulit serta tidak memiliki akses untuk meminjam dari sektor perbankan, BMT lembaga mikro yang menerapkan prinsip syariah cocok digunakan untuk masyarakat muslim, dan kemudahan dan modal yang relative kecil untuk membangun usaha BMT menuai kesuksesan di beberapa cabang BMT yang membuat masyarakat ingin mendirikan institusi yang sama, merupakan alasan BMT tumbuh dan berkembang dengan pesat. Hal itu di tandai dengan mendapat penghargaan dari masyarakat, namun dibeberapa cabang BMT juga mengalami kebangkrutan yang disebabkan oleh sikap yang tidak bijak. 


\section{Jurnal Ilmiah Ekonomi Islam, 7(01), 2021, 334}

Pembiayaan memberikan fasilitas persediaan dana guna memenuhi golongan yang termasuk dalam defisit unit (Aan, Rudi, \& Darwanto, 2018). Terhentinya berbagai macam aktivitas seperti pembatasan sosial berskala besar, penerapan kebijakan lockdown di beberapa Negara yang diselenggarakan guna mengantisipasi atau menurunkan jumlah lonjakan pasien positif covid-19, ternyata memiliki dampak yang cukup besar bagi bermacam sektor. Indonesia mengalami dampak pada sektor keuangan. Terlebih lagi pada sektor pembiayaan, dan salah satunya yang terdampak ialah lembaga usaha pembiayaan BMT. Hal ini membuat pendapatan masyarakat kian menurun. Sehingga sektor usaha yang memiliki pinjaman di BMT Hubbul Wathon mengalami kesulitan dalam pembayaranya. Apabila masalah tersebut hanya dibiarkan, maka akan mempengaruhi tingkat kesehatan Baitul Maal wa Tamwil (BMT).

BMT Hubbul Wathon Sumowono mengalami permasalahan dalam penyaluran kredit, dimana ketidakmampuan debitur untuk membayar sesuai jangka waktu tertentu (kredit macet). Sektor keuangan ini diharapkan dapat mengatasi guncangan ekonomi dimana Usaha Lembaga Keuangan Mikro di atur sesuai dengan POJK No 13/ POJK.05/2014, sedangkan Pembinaan dan Pengawasan Lembaga Keuangan Mikro di atur dengan No 14/POJK.05/2014 (OJK, 2014). Oleh karena itu, sekiranya perlu dilakukan kajian kembali berupa menguraikan masalah dengan lebih komprehensif dan sistematis agar dapat dihadapi oleh BMT dengan cara yang lebih efisien serta memudahkan masyarakat dalam melakukan aktivitas ekonomi. Diharapkan penelitian ini masyarakat dapat membantu dan mendukung serta yakin dengan pentingnya berkontribusi guna menopang ekonomi kerakyatan di berbagai daerah terjangkit pandemi Covid-19.

\section{Kajian Pustaka \\ Baitul Maal wa Tamwil}

Baitul Maal wa Tamwil (BMT) yaitu lembaga keuangan mikro yang dalam menjalankan praktiknya berlandaskan aturan syari'ah seperti membagi keuntunganya dengan menggunakan sistem bagi hasil untuk rasa kepedulian terhadap golongan yang kurang mampu (Solikhul, 2018). Baitul Maal merupakan lembaga sosial yang menerima amanah, dana masyarakat baik zakat, infaq, dan shadaqah untuk kepentingan sosial yang dalam penyaluran dananya menggunakan prinsip syari'ah. Sedangkan Baitul
Tamwil berfungsi sebagai pengembangan dana masyarakat dalam bentuk simpanan atau menabung untuk meningkatkan kualitas ekonomi (Muh Awal, 2015). Dalam kegiatan jual beli dengan akad Murabahah, Salam, Istishna' serta kegiatan bagi hasil dengan akad Mudharaah, Musyarakah, dan ijarah adalah ciri khas sistem lembaga keuangan berbadan koperasi dalam menumbuhkan bisnis usaha mikronya dan menyalurkan sebuah pembiayaan.

\section{Penyelesaian Sengketa}

Penyelesaian sengketa merupakan bagian dari sebuah perjanjian yang bersifat open system, karena terkait dengan choice of low (pilihan hukum) dan choice of form (pilihan form), dan yang mempunyai tanggung jawab penuh yaitu pihak yang bersengketa. Dalam konsep agama Islam ada tiga caara dalam menyelesaikan perselisihan yaitu secara damai (asshulh), arbitrase (al-tahkim), dan melalui lembaga peradilan atau al-qadha (Wijayanti, 2013).

\section{Pembiayaan Bermasalah}

Pembiayaan bermasalah atau Non Performing Loan (NPL) yaitu, dimana kualitas pembiayaanya kurang lancer atau macet (Ubaidillah, 2018). Pembiayaan bermasalah termasuk dalam kategori kualitas pembiayaan yang diatur Berdasarkan Pasal 4 Surat keputusan Direktur Bank Indonesia Nomor 30/267/KEP/DIR tanggal 27 Februari 1998. Menurut Susilo (2015) pembiayaan bermasalah mempunyai karakteristik, yaitu:

a. Adanya keterlambatan angsuran pokok dan bunga yang melebihi 270 hari.

b. Jika mengalami kerugian maka akan ditutup dengan pinjaman baru.

Berdasarkan latar belakang yang telah dijelaskan, penelitian ini memiliki tujuan untuk menjelaskan beberapa penanganan pembiayaan bermasalah di BMT Hubbul Wathon Sumowono selama masa Pandemi Covid-19 dengan menggunakan prinsip syariah.

\section{METODE PENELITIAN}

Penelitian ini dilakukan dengan pendekatan yang bersifat kualitatif deskriptif melalui wawancara, yaitu penelitian yang menggambarkan peristiwa untuk mendapat kesimpulan secara umum (Singarimbun, 1989). Dalam melaksanakan wawancara, peneliti bersama pihak yang terkait pada lembaga BMT Hubbul Wathon dilakukan secara daring guna mematuhi protokol kesehatan dari pemerintah akibat pandemi Covid-19. Esterberg mengatakan wawancara 
merupakan pertemuan dua orang dengan tanya jawab untuk mendapat informasi dalam satu topik yang sama (Sugiyono, 2008). Peneliti juga menggunakan metode library research (kepustakaan) yaitu mengambil dari beberapa referensi artikel, jurnal-jurnal yang telah dipublikasikan sesuai dengan fenomena dan realitas ekonomi.

\section{HASIL DAN PEMBAHASAN}

\subsection{Hasil penelitian}

Penelitian ini diambil dari wawancara secara daring melalui platform yang bernama zoom dengan Bapak Muhammad Fauzan selaku Manajer BMT Hubbul Wathon Sumowono. Dengan visi utamanya yaitu BMT yang amanah, teladan, sehat, profesional serta mampu meningkatkan kesejahteraan anggota dan pengelola. Terdapat Dewan Pengawas Syariah dalam BMT Hubbul Wathon karena lembaga tersebut menjalankan pelayanan institusi keuangan menggunakan prinsip syariah. Pasal 14 ayat 1 menjelaskan bahwa KSPPS wajib memiliki Dewan Pengawas Syariah. Peran sebagai Dewan Pengawas Syariah itu sendiri tentunya melihat bagaimana akadakad itu dilakukan oleh LKS (Ulin, 2018).

Dari penelitian ini kami akan menguraikan jawaban atas pertanyaan bagaimana gambaran umum perihal BMT Hubbul Wathon, bagaimana perkembangan anggota nasabah di BMT Hubbul Wathon. Selain itu, fokus utama dari penelitian ini adalah mengetahui seberapa besar lonjakan kredit macet yang terjadi di BMT Hubbul Waton akibat dari adanya pandemi covid-19 di Indonesia yang terjadi sejak maret lalu.Karena seperti yang telah diketahui, pandemi ini telah melumpuhkan perekonomian hampir di seluruh negara termasuk Indonesia. berikut grafik yang menyajikan kemerosotan perekonomian Indonesia karena adanya pandemi virus covid-19:

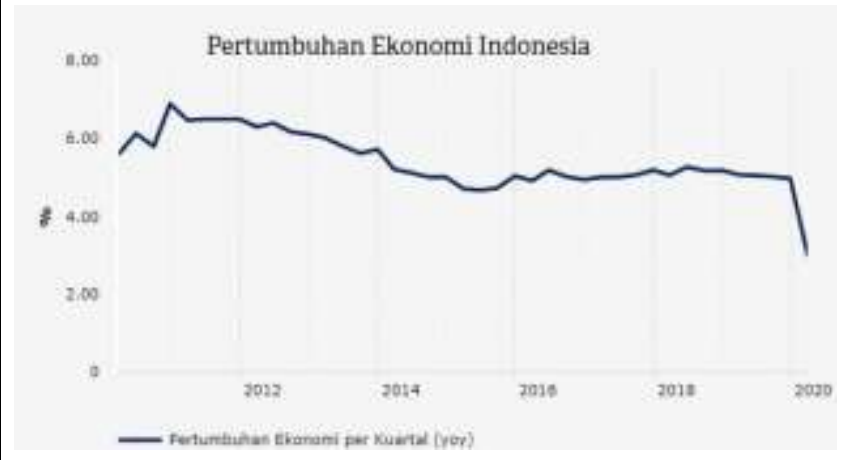

Sumber: Badan Pusat Statistik, Agustus 2020

Gambar 1 : Pertumbuhan Ekonomi Indonesia Tahun 2012-2020
Mengutip dari cnbcindonesia.com, pertumbuhan ekonomi kwartal ke II di Indonesia mengalami penurunan tajam kebawah sebesar 5,32\% dari pertumbuhan ekonomi kwartal ke II di tahun 2019 bila dilihat dari sisi tahun ke tahun (year to year). Sedangkan, Badan Pusat Statistik mengumumkan bahwa pada tingkat kwartal, kwartal ke II pertumbuhan ekonomi Indonesia mengalami penurunan sebesar $-4,19 \%$ dari kwartal I. Ini membuktikan bahwa pandemi virus covid-19 melumpuhkan perekonomian Indonesia bahkan bisa saja mengantarkan Indonesia ke jurang resesi apabila dilihat dari kedua kwartal tersebut. Sri Mulyani sebagai Mentri Keuangan Indonesia juga mengatakan bahwa pada kwartal ke III Indonesia bisa saja mengalami resesi apabila tidak ada penanganan yang cukup efektif dari pemerintah dalam menangani masalah perekonomian saat ini, menurutnya pemulihan ekonomi saat ini akan terasa lebih sulit jika tidak ada penanganan khusus karena bidang-bidang utama yang mendukung perekonomian Indonesia seperti bidang pariwisata, konsumsi ikut terseret cukup dalam karena adanya pandemi ini (Putri, 2020). Selain itu, fokus penelitian ini juga mengarah kepada apa penanganan yang diterapkan oleh BMT Hubbul Waton terhadap terjadinya kredit macet akibat terjadinya pandemi covid-19 ini. Berikut adalah penjabaran dari hasil penelitian yang kami lakukan:

Perkembangan Penyaluran Pembiayaan Baitul Maal wa Tamwil (BMT)

Berikut ini merupakan data yang menunjukan perkembangan jumlah anggota tahun 2018-2019:

Tabel 1: Perkembangan Anggota BMT

\begin{tabular}{|c|c|c|}
\hline No & Tahun & Anggota \\
\hline 1 & 2018 & 6516 \\
\hline 2 & 2019 & 7252 \\
\hline
\end{tabular}

Sumber: BMT Hubbul Wathon

Tabel diatas menjelaskan bahwa anggota BMT pada tahun 2018 mencapai sekitar 6.516 anggota. Sedangkan pada saat periode 2019 mengalami peningkatan yaitu menjadi 7.252 anggota. Hal ini membuktikan bahwa BMT dapat berkembang sesuai dengan kondisi perekonomian pada saat itu. Kemudian untuk tahun 2020 saat ini, Covid-19 juga menghambat lembaga BMT dimana 326 BMT terdapat dalam PBMT (Permodalan BMT) mempunyai permasalahan pembiayaan dan juga permasalahan liquiditas karena wabah Covid-19 
(KNKS, 2020). Berikut ini data penyaluran kredit UMKM di Indonesia sampai dengan Desember 2019:

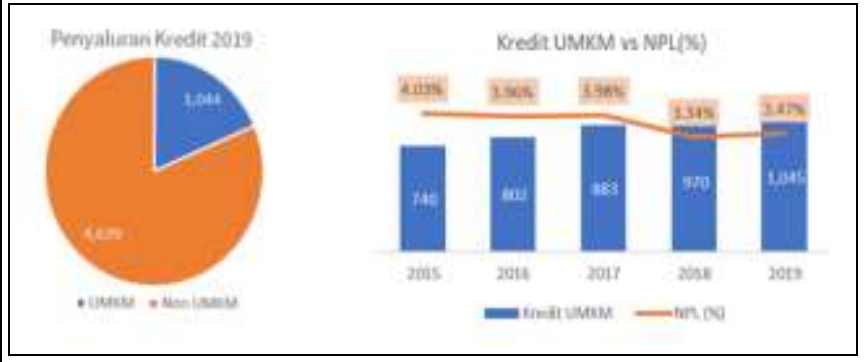

Sumber: Statistik Perbankan Indonesia, OJK 2019

\section{Gambar 2: Data Penyaluran Kredit UMKM di Indonesia Tahun 2015 - 2019}

Berdasarkan data yang tertera di atas, total dana yang disalurkan oleh perbankan untuk kredit UMKM sejak tahun 2015 hingga tahun 2019 rata-rata 52,34\% nya ada pada sektor perdagangan,sisanya sekitar $12,10 \%$ ada pada sector pariwisata, sector peneydia akomodasi makanan dan minuman serta transportasi. Semua sector tersebut adalah sector yang paling terdampak akibat pandemic virus covid-19 ini. Dengan melihat grafik data pada tahun 2019 yang disajikan memperlihatkan bahwa bisa saja terjadi ketidakmampuan pembayaran kredit, yang menyebabkan kredit macet dan meningkatkan nilai Non Performing Loan perbankan sebesar 500 triliun. Non Performing Loan yang meningkat akan mempengaruhi pendanaan perbankan. Hal ini di buktikan dengan turunnya harga saham perbankan secara drastis pada Maret 2020. Perbankan dihadapkan dengan peformanya yang menurun pada saat itu, namun tetap harus menjalankan tugasnya sebagai penggerak perekonomian Indonesia.

\section{Kenaikan Kredit Macet di Baitul Maal wa Tamwil Hubul Wathon}

Hasil yang kami dapatkan dari wawancara daring dengan Bapak Muhammad Fauzan selaku Manajer BMT Hubbul Wathon Sumowono mengenai presentase lonjakan kredit macet akibat pandemi virus covid-19 di BMT Hubbul Waton ialah, narasumber berkata terjadi lonjakan sebanyak 5\% pada produk pembiayaan dari kemacetan kredit yang terjadi sebelum pandemi covid-19 terjadi di Indonesia. Narasumber mengatakan, lonjakan ini cukup signifikan karena mengingat arus pendanaan di BMT itu sedikit tidak sebanyak arus pendanaan yang ada pada institusi perbankan. Narasumber juga mengatakan, kredit macet ini disebabkan oleh banyak sedikitnya nasabah yang terkena PHK ataupun terkena dampak potong gaji, sedangkan nasabah yang menggunakan produk pembiayaan di BMT Hubbul Waton ialah para pedagang umkm yang jelas terkena dampak paling serius akibat adanya pandemi virus ini seperti sehingga kebanyakan nasabah menunda membayar kreditnya kepada kami akibat kesulitan dalam masalah perekonomian.

\section{Produk Simpanan dan Produk Pembiayaan}

\section{a. Produk Simpanan}

1) Si Rela (Simpanan Sukarela Lancar) Sirela merupakan simpanan yang dapat diambil sewaktu-waktu.

Syarat ketentuan dan karakteristik:

- Menggunakan akad wadi'ah yadhomanah

- Setoran awal minimal Rp. 10.000,-

- Dilakukan sesuai jam kerja

2) Si Suka (Simpanan Sukarela Berjangka ) Syarat ketentuan dan karakteristik:

- Menggunakan akad wadi'ah yadhomanah dan mudharabah

- Setoran minimal Rp 3.000.000,-

- Jangka waktu jatuh tempo : 3 bulan, 6 bulan, 12 bulan.

3) Si Supel (Simpanan Sukarela Pelajar) Syarat ketentuan dan Karakteristik :

- Menggunakan akad wadi'ah yadhomanah.

- Setoran awal minimal Rp 5.000, untuk selanjutnya minimal Rp 2.000,-

- Dilakukan sesuai jam kerja

4) Si Suqur ( Simpanan Persiapan Ibadah Qurban)

Syarat ketentuan dan Karakteristik

- Menggunakan akad wadiah yadhomnah

- Setoran awal minimal Rp 50.000, untuk selanjutnya minimal Rp 10.000,-

- Dapat diambil 1 bulan sebelum hari raya Idul Adha

- Dilakukan sesuai jam kerja

5) Simpanan Pembiayaan

6) Simpanan Wadi'ah

7) Si Fitri ( Simpanan Persiapan Idul Fitri)

b. Produk Pembiayaan

1. Mudharabah (MDA)

Mudharabah yaitu bentuk akad kerja sama atau perjanjian yang dilakukan oleh dua pihak dimana pihak pertama (BMT selaku shahibul maal) akan menyediakan semua modal usaha, 
sedangkan pihak kedua (anggota BMT/Mudharib) akan bertindak sebagai pengelola usaha yang akan dijalani nantinya dan hasil dari usaha tersebut akan dibagi antara anggota BMT dan BMT sesuai dengan kesepakatan yang dibuat di persetujuan awal.

2. Musyarakah (MSA)

Musyarakah merupakan bentuk akad yang dilakukan oleh BMT dan dengan anggota BMT untuk mendukung dalam membangun usaha tertentu, yang dalam pelaksanaannya masing-masing pihak memberikan kontribusi berupa dana (modal usaha). Dalam akad ini keuntungan dan risiko usaha akan ditanggung bersama antara BMT dengan anggota BMT sesuai kesepakatan yang dilakukan pada awal akad pembiayaan.

3. Murabahah (MBA)

Murabahah adalah suatu akad berbentuk jual beli yang dilakukan oleh suatu lembaga dengan nasabahnya. Dalam akad ini berarti suatu barang antara BMT (penjual) dengan anggota BMT (pembeli) dengan menegaskan harga belinya kepada anggota BMT dan anggota BMT membayarnya dengan harga yang lebih sebagai laba. Hal ini murni dilakukan dengan kesepakatan yang telah disetujui oleh kedua pihak.

4. Ijaroh (IJR)

Ijaroh merupakan akad yang berbentuk pemindahan hak guna (manfaat) dari suatu barang atau jasa dalam kurun waktu tertentu dengan adanya pembayaran sewa/upah. Dalam akad ini tidak adanya pemindahan pemilikan barang kepada pihak lain.

\subsection{Pembahasan}

Hasil penelitian yang kami dapatkan ini sama seperti penelitian yang dilakukan oleh Elgit Abdul Basit yang menjelaskan bahwa BMT Bina Usaha di Karangjati Kabupaten Semarang memiliki produk simpanan yaitu Simpanan Sukarela Lancar (Si Rela), Simpanan Sukarela Berjangka (Si Suka), Simpanan Sukarela Pelajar (Si Supel), Simpanan Sukarela Qurban (Si Suqur), Simpan Amanah (Si Aman). Simpanan Sukarela Lancar merupakan produk yang lebih diminati karena produk Si Rela menggunakan akad wadiah yang bersifat tolong menolong. (Elgit, 2016). Penelitian Dimas Saputra juga membahas mengenai produk BMT Atunnisa di kartasura yang menyebutkan bahwa di BMT tersebut tersedia Produk Pembiayaan Murabahah, Musyarakah, Murabahah dan Ijarah. Pada BMT Atunnisa akad sewa menyewa selain ijarah terdapat juga ijarah muntahiya bit tamlik. (Dimas, 2017),

Selanjutnya pada penelitian Ezzah May Farroh produk BMT Bina Ummat Sejahtera cabang Salatiga menyebutkan terdapat Produk Simpanan Sukarela Lancar (Si Rela), Simpan Sukarela Berjangka (Si Suka), Simpanan Sekolah, Simpanan Sukarela Pendidikan (Si Sidik), Simpanan Haji dan Umrah (Si Haji dan Umrah), Simpanan Hari Raya Idul Fitri (Si Hafit), dan Simpanan Produk Masa Depan ( $\mathrm{Si}$ Mapan). (Ezzah, 2019), Lalu terdapat dua produk pembiayaan, pertama modal kerja dengan akad Mudharabah (bagi hasil), kedua Pembiayaan Jual Beli Barang dengan akad Murabahah. Hal ini membuktikan produk pada BMT sebagian besar sama berdasarkan asas saling menolong dan kekeluargaan. Sehingga dapat kita ambil kesimpulan bahwa BMT dapat mempermudah masyarakat untuk mengambil pinjaman dan melakukan simpanan di cabang BMT manapun karena produk yang ditawarkan cendrung memiliki banyak kesamaan. BMT Hubbul Wathon didirikan dengan tujuan untuk meningkatkan ekonomi rakyat di desa sumowono. Dengan adanya produk ini diharapkan pembiayaan dapat tersalurkan guna memperkuat modal usaha mikro di desa sumowono.

Akibat Pandemi Covid-19 BMT Hubbul Wathon mengalami Permasalahan Pembiayaan sebesar 5\% dari pembiayaan bermasalah sebelum pandemi. Menurut narasumber terkait, solusi yang diterapkan untuk menghapi kredit macet selama pandemi ini ialah dengan meningkatkan likuiditas BMT yaitu dengan cara menekankan atau mengurangi produk pembiayaan lancar agar dapat mengurangi dana yang beredar dan mengurangi jumlah penggunaan kas BMT guna menjamin keuangan agar tetap stabil dan tidak terganggu akibat kredit yang tidak lancar, selain itu ialah dengan cara tetap menjalin hubungan baik dengan nasabah, menyelesaikan segala sesuatu yang berhubungan dengan kredit macet ini dengan kekeluargaan agar nasabah merasa nyaman dan ingat tanggung jawabnya kepada kami selaku wadah pembiayaan mereka. Serta solusi lain yang disiapkan BMT ialah menambah anggota nasabah baru agar lebih meningkat.

Likuiditas sangat penting bagi BMT dalam menjalankan kegiatannya, seperti mengatasi kekurangan dana, memuaskan nasabah untuk 
pembiayaan dan memberikan fleksibilitas untuk investasi. Likuiditas dapat diartikan juga dengan kemampuan perusahaan dalam membayar kewajibankewajiban yang wajib dipenuhi (Eko, 2018). Dalam mengukur sebuah likuditas apabila sudah memenuhi syarat dikatakan "likuid" dilihat melalui Rasion Lancar (currentratio), Rasio Kas (cashratio), dan Rasio Cepat (quickratio). Likuiditas yang tersimpan tidak boleh terlalu kecil karena dapat mengganggu pekerjaan maupun terlalu besar karena bisa menurunkan efisiensi dan berpengaruh terhadap rendahnya tingkat profitabilitas. Pada pembatasan pembiayaan pihak BMT bisa melaukan pemilihan untuk memberikan atau tidak memberikan pembiayaan kepada anggotanya. Pada penilitian lain (Eko, 2018) menunjukkan bahwa masalah risiko yang terjadi pada BMT dapat dicegah dengan menerapakan prinsip yang akan memudahkan petugas dalam memilih calon anggota dan anggota yang sesuai dan layak untuk diberikan pinjaman, prinsip tersebut adalah 5C + 1S (Buchori, 2012), yakni:

a. Character (Karaktek)

Dalam hal ini petugas akan melihat melalui kondisi keluarga dan lingkungan sekitar calon anggota atau anggota yang akan mengajukan pembiayaan. Petugas juga akan melakukan pendekatan kepada kepala tokoh masyarakat setempat tentang karakter dan kehidupan seharihari agar mendapatkan kepercayaan dalam pembiayaan.

b. Condition of Economy (Kondisi Usaha)

Kondisi lingkungan usaha seperti kondisi politik, sosial, ekonomi maupun budaya dapat mempengaruhi seseorang dalam mendirikan sebuah usaha. Usaha yang dijalankan tentunya harus mempunyai kondisi yang baik untuk kebutuhan karyawan maupun keluarganya. Maka dari itu kondisi tersebut akan menjadi patokan petugas dalam memberikan pembiayaan kepada anggotanya.

c. Capacity (kemampuan)

Kemampuan anggota akan ditinjau oleh petugas BMT dalam menjalankan aktivitas usahanya yang nantinya akan digunakan untuk melaksanakan kewajiban melunasi tanggungan pembiayaan yang telah disetujui oleh anngota maupun oleh pihak BMT.

d. Capital (Modal)

Pihak BMT akan melakukan perhitungan jumlah modal pembiayaan kepada BMT. Hal ini dilakukan agar meminimalkan risiko yang akan terjadi di kemudian hari jika modal yang dimiliki anggotanya tidak sesuai dengan ketentuan yang dimiliki oleh BMT.

e. Collateral (Jaminan)

Pihak BMT akan melakukan pengecekan terhadap barang jaminan yang akan digunakan oleh anggotanya. Hal ini dilakukan agar barang jaminan yang diserahan tidak mendatangkan kesusahan dalam pembayaran. Adapun dua fungsi barang jaminan, yaitu cadangan pelunasan jika tidak mampu membayar kewajibannya. Tetapi pihak BMT sendiri tidak akan langsung menarik jaminan tersebut, melainkan memberi waktu agar anggotanya mencai alternative lain yang nantinya akan disepakati bersama. Kedua, jaminan digunakan apabila anggota melakukan gagal bayar dalam waktu yang telah ditentukan.

f. Syariah

Prinsip ini dilakukan jika melihat bidang usaha yang akan melakukan pinjaman pembiayaan tidak bertentangan dengan Syariah dan akan dikaji lagi dengan kesuaian kebutuhan pembiayaan dengan berdasarkan prinsip Islam.

Dengan demikian pihak BMT Hubbul Wathon juga dapat melakukan penambahan anggota baru dengan memberikan pelayanan dan keunggulan produk yang terbaik. Pendekatan dengan calon anggota dapat dilakukan untuk memberikan citra baik BMT. Dalam melakukan pendekatan dan keakraban dengan calon anggota, pihak BMT herus menjadi bagian yang baik dan memberikan solusi permasalahan bagi para anggotanya.

\section{KESIMPULAN}

Dilihat dari segi produktivitas kemampuan menghasilkan pendapatan bagi BMT Hubbul Wathon, adanya pembiayaan bermasalah mengakibatkan menurunnya pendapatan BMT hingga tidak adanya pendapatan sama sekali. Risiko lainnya adalah kewajiban BMT Hubbul Wathon dalam memperbesar dana (PPAP) Pencadangan Penyisihan Penghapusan Aktiva Produktif. PPAP yang besar dapat menurunkan produktifitas dana BMT. Sedangkan dari lingkup nasional, yaitu dapat mengurangi kontribusi BMT Hubbul Wathon dalam menjalankan fungsinya sehingga perannya sebagai funding (pengumpulan dana) maupun landing (penyaluran dana) bagi masyarakat menjadi tidak optimal. 
Solusi yang diterapkan untuk menghapi pembiayaan bermasalah di BMT Hubbul Wathon selama pandemi ini ialah dengan meningkatkan likuiditas BMT yaitu dengan cara menekankan atau mengurangi produk pembiayaan lancar agar dapat mengurangi dana yang beredar dan mengurangi jumlah penggunaan kas BMT guna menjamin keuangan agar tetap stabil dan tidak terganggu akibat kredit yang tidak lancar, selain itu ialah dengan cara tetap menjalin hubungan baik dengan nasabah, menyelesaikan segala sesuatu yang berhubungan dengan kredit macet ini dengan kekeluargaan agar nasabah merasa nyaman dan ingat tanggung jawabnya kepada kami selaku wadah pembiayaan mereka. Serta solusi lain yang disiapkan BMT ialah menambah anggota nasabah baru agar lebih meningkat.

Dari hasil penelitian ini, BMT Hubbul Wathon dalam memberikan pembiayaan sudah sesuai dengan prinsip syari'ah. Dengan demikian beberapa saran untuk lembaga BMT dalam menghadapi krisis ekonomi pada saat Pandemi Covid-19, seperti halnya realisasi zakat pada saat ini yang masuk ke BAZNAS tidak sesuai. Oleh karena itu, sebaiknya penyaluran zakat lebih lagi difokuskan kepada fakir miskin yang terdampak Pandemi Covid-19 ini sesuai dengan data mustahik yang benar.

\section{UCAPAN TERIMA KASIH}

Penulis mengucapkan terima kasih kepada Dosen Prodi Ekonomi Islam, JSI-FIAI-UII, mahasiswa Ekonomi Islam, dan pihak - pihak BMT Hubbul Wathon Cabang Sumowono serta seluruh pihak yang telah memberikan motivasi, dorongan dan doa, sampai kini penulis mampu menyelesaikan penelitian. Semoga Allah SWT membalas dengan rahmat, nikmat, dan hidayah yang jauh lebih baik, Amiin. Jazakumullah Khairan Katsiran.

\section{REFERENSI}

Aan, Z. A., Rudi, J. L., \& Darwanto. (2018). Analisa Majamen Pembiayaan Macet. Jurnal Ekonomi Islam, 9 (1), 1-20.

Aldi, Andika, \& Yodi. (2020, Maret 25). Ancaman

Krisis di Sektor Keuangan Mikro Syariah. Retrieved from KNKS.go.id: https://knks.go.id/berita/235/ancaman-krisis-disektor-keuangan-mikro-syariah?category=1

Buchori, N. S. (2012). Koperasi Syari'ah dan Praktek.
Dimas, S. (2017). Respons Masyarakat terhadap Produk Pembiayaan BMT di Kartasura. Journal of Multidisciplinary Studies, 1 (2), 244-256.

Edi, S. (2015). Manajemen Pembiayaan dan Risiko Pembiayaan Bank Syari'ah. 1.

Eko, L. P. (2018). Penerapan Manajemen Risiko Pembiayaan dalam Menjaga LIkuiditas dan Solvabilitas BMT. Skripsi.

Elgit, A. B. (2016). Analisis Produk Simpanan Sukarela Lancar (Si Rela) di BMT Bina Usaha Karang Jati Kecamatan Bergas Kabupaten Semarang. Skripsi.

Ezzah, M. F. (2019). Strategi Pemasaran Produk Si Mapan (Simpanan Masa Depan) di KSPPS BMT Bina Ummat Sejahtera Cabang Salatiga. Skripsi.

KEMENKEU, g. (2020, November 9). Kuartal III, Pembalikan Ekonomi 2020 Terjadi. Retrieved from

https://www.kemenkeu.go.id/publikasi/berita/ku artal-iii-2020-pembalikan-ekonomi-terjadi/

KNKS. (2020, April 17). Ancaman Krisis di Sektor Keuangan Mikro Syari'ah. Retrieved from https://knks.go.id/berita/235/ancaman-krisis-disektor-keuangan-mikro-syariah?category $=1$

Masri, S. (1984). Metode Penelitian.

Muh Awal, S. N. (2015). Urgensi Penerapan Islamic Corporate Governance di Baitul Maal Wat Tamwil (BMT). Jurnal Kajian Bisnis, 23 (1), 6470.

OJK. (2014). Peraturan $L K M$ - OJK. Retrieved from https://www.ojk.go.id/id/kanal/iknb/Pages/Perat uran-LKM.aspx

OJK. (2019). Statistik Perbankan Syari'ah. Retrieved from

https://www.ojk.go.id/id/kanal/syariah/data-danstatistik/statistik-perbankan-

syariah/Pages/Statistik-Perbankan-Syariah---

Desember-2019.aspx

Putri, C. A. (2020). Buka-bukaan Sri Mulyani: Resesi hingga Kans PDB Minus di Q3. Jakarta: CNBC Indonesia.

Solikhul, H. (2018). Persepsi Masyarakat terhadap Baitul Maal wa Tamwil dalam Pemberdayaan Ekonomi Masyarakat. al-Uqud: Journal of Islamic Economics, 2 (2), 198-212.

Sugiyono. (2008). Metode Penelitian Pendidikan:(Pendekatan Kuantitatif, Kualitatif dan R \& D). 
Jurnal Ilmiah Ekonomi Islam, 7(01), 2021, 340

Ubaidillah. (2018). Pembiayaan Bermasalah pada Bank Syari'ah: Strategi Penanganan dan Penyelesaianya. el-Jizya: Jurnal Ekonomi Islam, 6 (2), 287-310.

Ulin, N. (2018). Optimalisasi Peran Dewan Pengawas Syari'ah pada Lembaga Keuangan Mikro Syari'ah. Journal of Islamic Banking and Finance, 2 (2), 211-222.
Wijayanti, M. (2013). Pola Penyelesaian Sengketa Pembiayaan Bermasalah di Kalangan Ekonom Pegiat Ekonomi Syari'ah Kota Metro. Adzkiya: Jurnal Hukum dan Ekonomi Syari'ah, 1 (1), 111125.

Zulkifli, R., Zulfadli, H., \& Hamzah. (2016). Analisa Permasalahan Baitul Maal Wat Tamwil (BMT) melalui Pendekatan Analytical Network Process (ANP). Jurnal Al-Hikmah, 13 (1), 18-29. 